\title{
Protein supplementation and 48-hour calf re- moval effects on range cows
}

\author{
BOK F. SOWELL, JOE D. WALlACE, EUGENE E. PARKER, AND G. MORRIS \\ SOUTHWARD
}

\begin{abstract}
Authors are assistant professor, Dept. of Animal and Range Science, South Dakota State Univ.; professor and associate professor, Dept. of Animal and Range Science, and professor, Dept. of Experimental Statistics, New Mexico State Univ.. Las Cruces, 88003-0003.
\end{abstract}

\begin{abstract}
In 1984, 99 Angus $\times$ Hereford cows (4- to 6-yr-olds) were assigned randomly to a $4-y r, 2 \times 2$ factorial study. Treatment assignment was permanent, and no new cows were added during the study. By 1987, 71 cows remained, and over-all, 335 complete cow-calf data sets were used. Main effect treatments were beginning time (prepartum [PRE] vs postpartum [POST]) for crude protein (CP) supplementation (twice weekly feeding of $41 \% \mathrm{CP}$ cottonseed meal pellets at $1.58 \mathrm{~kg}^{\circ} \mathrm{cow}^{-1}$. feeding ${ }^{-1}$ ) and temporary calf removal (48 hour [48-H] vs 0 hour [CONT]) just before the breeding season. For analyses, sex of calf was included as a third main effect $(2 \times 2 \times 2)$ and year was included as a random factor; the 4-way interaction served as the testing term for repeated measures over years. Year was the dominant source of variation for most traits; we attributed this mainly to different amounts and timing of precipitation among years. Very few interactions were observed. The PRE supplemented cows had reduced $(P<0.01)$ spring body weight losses and higher prebreeding body condition scores ( 4.9 vs $4.5 ; P<0.01$ ) compared with POST cows. Reproductive performance did not differ between PRE and POST cows. Use of 48-H calf removal vs CONT did not influence $(P>0.10)$ reproductive traits measured. Likewise, 48-H treatment did not impair health or reduce weaning weights of calves. In a separate, withinyear analysis used to examine age of dam effects, productivity of 4-yr-old cows during 1984 was slightly below that of older cows for some traits. Cow age effects were not detected in other years. We conclude that control cows in our study were approaching optimum fertility and production levels in concert with their environment and that improvement beyond these levels with the treatments imposed was unlikely.
\end{abstract}

Key Words: reproduction, body condition, weaning weight, calving interval

Reproductive performance of range cows is associated closely with nutritional status (Short and Adams 1988). In much of the earlier research relating nutrition to reproduction, energy was the main diet constituent studied (e.g., Wiltbank et al. 1962); recent studies have focused more attention on the need for adequate dietary protein (Sasser et al. 1988, Randel 1990). Some studies have demonstrated clearly that crude protein (CP) supplementation influenced conception rates and calving intervals (Bellido et al. 1981, Clanton 1982), while others have failed to produce such responses (DelCurto et al. 1990, Sanson et al. 1990). Suckling and lactation effects on range cow reproduction appear to be equally as important as nutrition (Short et al. 1990, Williams 1990). By

\footnotetext{
The authors gratefully acknowledge clerical assistance of $\mathbf{R}$. Reynolds and programming assistance of $L$. Loehr.

Journal Article 1498 of the New Mexico Agr. Exp. Sta., Las Cruces.

Manuscript accepted 17 June 1991
}

partially alleviating lactation stress, short-term calf removal ( 36 to 72 hours) before the breeding period reduced postpartum anestrus in beef cows (Smith et al. 1979, Dunn et al. 1985) and improved conception rates in artificial insemination programs (Odde et al. 1986). This approach has not been evaluated thoroughly under range conditions where natural breeding is used. Therefore, our study examined the effects of 48-hour calf removal and the beginning time (pre- vs postpartum) for CP supplementation on reproductive performance and calf production by range beef cows. Our hypothesis was that prepartum CP supplementation, especially when combined with 48-hour calf removal, would increase productivity of range cows.

\section{Study Area}

The study was conducted at the Fort Stanton Experimental Ranch in the foothill-mountain region of southcentral New Mexico. Vegetation is dominated by blue grama (Bouteloua gracilis [H.B.K.]Lag.); other grasses include galleta (Hilaria jamesii [Torr.] Benth) and sand dropseed (Sporobolus cryptandrus [Torr.] Gray). Important forbs include carruth sage (Artemisia carruthii Wood) and scarlet globemallow (Sphaeralcea coccinea [Pursh.] Rydb.). Slopes support stands of pinyon-juniper (Pinus edulis Engelm., Iuniperus spp.) and wavyleaf oak (Quercus undulata Torr.). Precipitation during the growing season (June to August) was $66 \mathrm{~mm}$ for $1984,254 \mathrm{~mm}$ for $1985,325 \mathrm{~mm}$ for 1986 , and $198 \mathrm{~mm}$ for 1987 , compared with a long-term average of $226 \mathrm{~mm}$. Total precipitation for each year of the study except 1984 was above the long-term average of $348 \mathrm{~mm}$.

\section{Methods}

In 1984, 99 Angus $\times$ Hereford cows (4- to 6-yr-olds) were assigned randomly to the $4-y r, 2 \times 2$ factorially arranged study. Main effect treatments were beginning time (prepartum [PRE] vs postpartum [POST]) for winter-spring CP supplementation (twice weekly group feeding of $41 \% \mathrm{CP}$ cottonseed meal pellets at 1.58 $\mathrm{kg} \bullet \mathrm{cow}^{-1} \cdot$ feeding $^{-1}$ ) and temporary calf removal just before the breeding season ( 48 hour [48-H] vs 0 hour [CONT]). Cows remained assigned to their respective treatments throughout the study, and following initial assignment, no new cows were added. By 1987 (the final study year), 71 cows remained, and over the 4-yr period, 335 complete cow-calf data sets were used. Numbers of cows by treatment and age on the study each year as well as the number lost from the study and reason for loss (by year) are detailed in Table 1.

Supplementation for PRE treatment cows began in January and ended in either late April or early May; specific beginning and ending dates varied among years (Table 2). Supplemental feeding for cows on the POST treatment began in mid-March (Table 2) 
Table 1. Number of cows by treatment and age group and number lost due to various causes each year.

\begin{tabular}{lcccc}
\hline \hline & \multicolumn{4}{c}{ Year } \\
\cline { 2 - 5 } Category & 1984 & 1985 & 1986 & 1987 \\
\hline Total cows & 99 & 89 & 76 & 71 \\
Supplemental treat- & & & & \\
ment:1 & & & & \\
PRE & 50 & 44 & 37 & 35 \\
POST & 49 & 45 & 39 & 36 \\
Calf removal & & & & \\
treatment: & & & & \\
CONT & & 45 & 39 & 36 \\
48-H & 50 & 44 & 37 & 35 \\
Cow age group, (age): & 49 & & & \\
1 & $25(4)$ & $22(5)$ & $19(6)$ & $17(7)$ \\
2 & $30(5)$ & $26(6)$ & $23(7)$ & $21(8)$ \\
3 & $44(6)$ & $41(7)$ & $34(8)$ & $33(9)$ \\
Reason for loss: & & & & \\
Open & 8 & 8 & 5 & 7 \\
Death & & & & \\
Injury & 1 & 1 & 0 & 0 \\
Other & 1 & 0 & 0 & 1 \\
\hline
\end{tabular}

IPRE $=$ twice weekly feeding of cottonseed meal at $1.58 \mathrm{~kg}^{\circ} \mathrm{cow}^{-1} \bullet$ feeding ${ }^{-1}$ beginning prepartum; POST = same as PRE treatment, but feed only postpartum.

${ }^{2} \mathrm{CONT}=$ calves were not removed from cows prior to breeding season; $48-\mathrm{H}=$ temporary $(48 \mathrm{~h})$ calf removal before start of breeding season.

3Primary causes of death were lightning ( 2 head) and gunshot ( 2 head), presumably from "game hunters".

Table 2. Beginning and ending dates (Julian day of year) and length (days) of the supplemental feeding period for each treatment during each year.

\begin{tabular}{|c|c|c|c|c|}
\hline \multirow{2}{*}{$\begin{array}{l}\text { Treatment }{ }^{1} \\
\text { Date/time }\end{array}$} & \multicolumn{4}{|c|}{ Year } \\
\hline & 1984 & 1985 & 1986 & 1987 \\
\hline $\begin{array}{l}\text { PRE: } \\
\text { Beginning date } \\
\text { Ending date }\end{array}$ & $\begin{array}{r}24 \\
116 \\
\end{array}$ & $\begin{array}{r}18 \\
125 \\
\end{array}$ & $\begin{array}{r}20 \\
140 \\
\end{array}$ & $\begin{array}{r}15 \\
133 \\
\end{array}$ \\
\hline Total days & 92 & 107 & 120 & 118 \\
\hline $\begin{array}{l}\text { POST: } \\
\text { Beginning date } \\
\text { Ending date }\end{array}$ & $\begin{array}{r}74 \\
116 \\
\end{array}$ & $\begin{array}{r}74 \\
125 \\
\end{array}$ & $\begin{array}{r}76 \\
140 \\
\end{array}$ & $\begin{array}{r}71 \\
133 \\
\end{array}$ \\
\hline Total days & 42 & 51 & 64 & 62 \\
\hline
\end{tabular}

'See Table 1 for description of treatments.

and ended the same day as for the PRE group. Just before the start of supplementation each year, PRE cows were moved to a separate pasture from that occupied by POST cows. Once POST treatment supplementation began, cows from both supplemental groups were moved to a common pasture and fed together until supplementation was terminated.

During the temporary calf removal period, $48-\mathrm{H}$ calves were penned separately from, but in full view of their dams, and near the watering point used by the cows. While separated from their dams, 48-H calves had access to fresh drinking water, an open shed, and were provided (on a group basis) alfalfa hay $(17 \% \mathrm{CP})$ and a grain $\operatorname{mix}(14 \% \mathrm{CP})$ at 0.9 and $0.45 \mathrm{~kg} \cdot$ calf $^{-1}$, respectively, for the 48-hour period.

\section{Cow and Calf Performance Traits Measured}

Seven traits involving both the cows and their offspring were measured to evaluate treatment effects. Calf traits included birth date, weight at weaning (both actual and 205-day adjusted), and daily gain from birth to weaning. Measurements on the cows were body condition (BC) score, fall pregnancy rate, calving interval, and body weight (BW) changes during different periods of the year. The 7 data collection procedures involved in accumulating these measures were: (1) birth date for each calf was recorded on a Julian day basis; (2) all calves were weighed individually at weaning each year (weaning dates were October $4,13,15$, and 2 , respectively, from 1984 through 1987); (3) calf gains were calculated as weaning weight minus a common birth weight $(34 \mathrm{~kg})$ divided by weaning age in days; (4) individual cows were scored visually for $\mathrm{BC}$ using a scale from 1 (emaciated) to 9 (obese) according to Richards et al. (1986); for all years except 1986, the BC scoring was performed by the same experienced observer (In 1986, a different, less-experienced observer scored each cow.); (5) cows were pregnancy-tested by rectal palpation each year at fall weaning (see $\# 2$ above for weaning dates) and any open or unsound cows were culled. The number of open cows removed from the study each year is shown in Table 1. In 3 cases during the study, cows were removed during the summer because of calf losses; these cows were diagnosed as open but were exposed to a comparatively short breeding season, i.e., about 30 days; (6) calving interval was calculated by taking the difference between consecutive calving dates and adding 365 days; (7) cows were weighed before calving (January), after calving (April), and at fall weaning (October) and BW changes for each cow were calculated for the periods January to April, April to October, and January to October.

\section{Routine Management of the Cow Herd}

Except for the period when PRE treatment cows were separated from POST cows for early supplementation, all cows on the study were maintained together and managed as 1 unit. Stocking rate varied within and between years because of varying forage conditions, but overall, averaged $16 \mathrm{ha} / \mathrm{cow}$ on a yearlong basis. All calves were branded and given calfhood vaccinations, and male calves were castrated, in mid-April each year. Cows were exposed to fertile, 2- to 5-yr-old Simmental bulls (12 to 18 cows/bull) beginning in late April for a 90 day period, and the subsequent calving season began about 1 February each year. A salt:mineral mix ( $50 \%$ dicalcium phosphate: $45 \%$ salt: and $5 \%$ cottonseed meal on an as-fed basis) was provided for all cows throughout the study.

\section{Statistical Analyses}

Supplementation (PRE vs POST), calf removal (48-H vs CONT) and sex of calf (steer vs heifer) were arranged as main effects in a $2 \times 2 \times 2$ factorial structure. Treatments were imposed over $4 \mathrm{yr}$, and year was considered as a random variable, i.e., a surrogate for environmental conditions. The experiment was considered as a split-plot in time with a completely randomized experimental design in the main plot and was analyzed using GLM procedures of SAS (1985). The four-way interaction (supplement $X$ calf removal $X$ sex of calf $X$ year) served as the testing term for the repeated measures over year. Age of cow was confounded with year; however, the effect of environmental conditions, as represented by year, was considered to be of greater importance than changes in cow age, especially because all age groups represented are classed as mature cows (BIF 1990) with the exception of 4-yr-old cows in 1984. Nonetheless, the effect of age of dam was examined using a completely random design on a within-yr basis. When significant $(P<0.05)$ cow age effects were detected, age group combinations were compared by single degree of freedom linear contrasts (e.g., 4-yr-olds vs $\bar{x}$ of 5- and 6-yr-olds in 1984). Fall pregnancy percentages were tested with chi-square analysis using the CATMOD procedure of SAS (1985). 


\section{Results and Discussion}

\section{Age of Dam Effects}

Only in 1984 did cow age measurably influence $(P<0.05)$ any of the traits studied; therefore, comparative data among cow age groups for 1985 through 1987 are not presented. Differences in production traits between 5- and 6-yr-olds in 1984 were small; however, for certain traits, 4-yr-old cows appeared somewhat less than the 2 older age groups. Thus, productivity of 4 -yr-olds was compared (by orthogonal contrast) with that of the mean from 5-and 6-yr-olds.

Average birth date for calves from 4-yr-old cows was 11 days later $(P<0.05)$ in the 1984 calving season than that for calves from older cows (Table 3). Consequently, because they were younger at

Table 3. Comparison of productivity by cow age group in 1984.

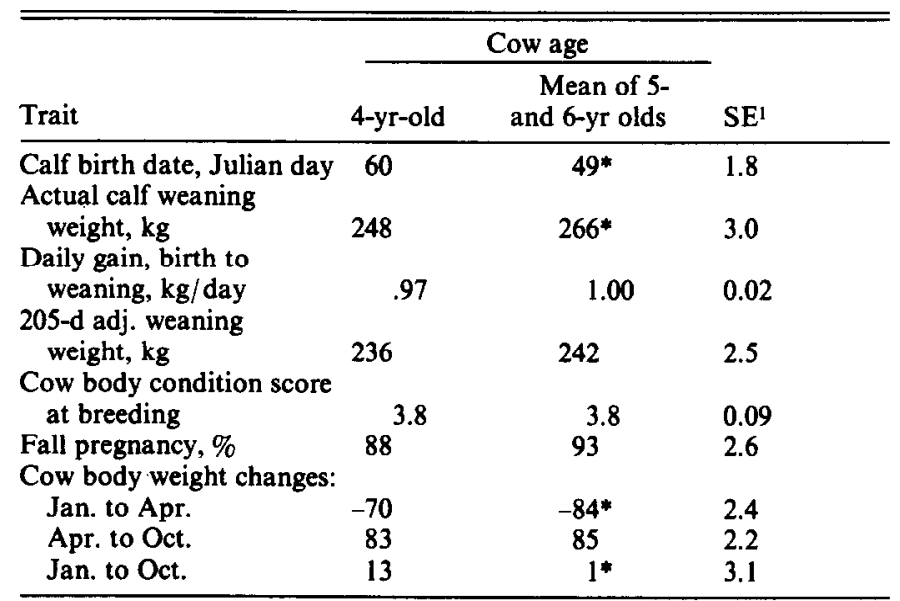

*Significantly different $(P<0.05)$ from 4 -yr-olds.

'SE = standard error $(\mathrm{N}=25,30$, and 44 for 4 -, 5-, and 6-yr-olds, respectively).

weaning, calves from the 4-yr-old cows had lower $(P<0.05)$ actual weaning weights than calves from 5 - and 6-yr-old cows. Other calf traits considered (gain from birth to weaning and 205-day adjusted weaning weights), along with cow $\mathrm{BC}$ at breeding and fall pregnancy percentages, did not differ $(P>0.05)$ between age groups.

The 4-yr-old cows lost less $(P<0.05) \mathrm{BW}$ during the spring calving, supplemental feeding period (January to April) and gained more $(P<0.05)$ BW from precalving until fall weaning (January to October) compared with the average BW changes from 5- to 6-yr-olds during these same time periods (Table 3 ).

It was not surprising that 1984 proved to be the only year in which age of dam effects were pronounced; 1984 was the only year that included a cow age group (4-yr-olds) recommended for receipt of an additive correction $(9.1 \mathrm{~kg})$ to calf weaning weights in order to place them on an equal basis with mature (5- to 10-yr-old) cows (BIF 1990). Moreover, as indicated previously, growing season precipitation in 1984 was considerably below the long-term average. During other years, precipitation occurring in the growing season was either above (1985 and 1986) or only slightly below (1987) the long-term average. It is generally accepted that unfavorable range forage conditions (or lower nutrient intake) is more detrimental to younger cows than to mature cows (Wallace 1988 , Bellows et al. 1982).

\section{Analysis of Variance Components and Year Effects}

The analysis of variance components and resulting levels of significance for various production traits studied are shown in Table 4. Our results were characterized by a very limited number of interactions; this served as justification for the added emphasis on main effect discussions that follow. There was a strong and consistent influence of year on practically every trait considered (Table 4). Previous long-term ( $5 \mathrm{yr}$ ) studies conducted at the same location (Bellido et al. 1981, Judkins et al. 1985), along with the present study, show that performance of range cows is typically influenced more by year than by experimental treatments imposed. The marginally significant $(P<0.10)$ three-way (supplement $X$ calf removal $X$ year) and four-way (supplement $X$ calf removal $X$ sex of calf $X$ year) interactions observed for some traits all involve year and probably represent, for the most part, a carry-over effect from the influence of year itself on many of the traits studied.

As discussed previously, drier conditions during the 1984 growing season may have been involved in the age of dam influence (production of 4-yr-olds $<$ the $\bar{x}$ of 5-and 6-yr olds) noted that year (Table 3). Compared with the long-term average, the 1987 growing season also was somewhat lower in precipitation (198 vs $226 \mathrm{~mm}$ ), whereas, both 1985 and 1986 were above the long-term average in growing season precipitation (254 and $326 \mathrm{~mm}$, respectively).

Table 4. Analysis of variance and levels of significance for various production traits.

\begin{tabular}{|c|c|c|c|c|c|c|c|c|c|c|}
\hline \multirow[b]{2}{*}{ Source } & \multirow[b]{2}{*}{$\mathrm{df}^{1}$} & \multirow{2}{*}{$\begin{array}{l}\text { Birth } \\
\text { date }\end{array}$} & \multirow{2}{*}{$\begin{array}{l}\text { Actual } \\
\text { calf } \\
\text { weaning } \\
\text { weight }\end{array}$} & \multirow{2}{*}{$\begin{array}{l}\text { Calf } \\
\text { daily gain, } \\
\text { birth to } \\
\text { weaning }\end{array}$} & \multirow{2}{*}{$\begin{array}{l}\text { 205-day } \\
\text { adjusted } \\
\text { weaning } \\
\text { weight }\end{array}$} & \multirow{2}{*}{$\begin{array}{l}\text { Calving } \\
\text { interval }\end{array}$} & \multirow{2}{*}{$\begin{array}{l}\text { Cow body } \\
\text { condition } \\
\text { at breeding }\end{array}$} & \multicolumn{3}{|c|}{ Cow body weight changes } \\
\hline & & & & & & & & Jan.-Apr. & Apr.-Oct. & Jan.-Oct. \\
\hline Total & 334 (235) & & & & & & & & & \\
\hline Supplement (S) & 1 & NS & NS & NS & NS & NS & $* *$ & $* *$ & * & $\dagger$ \\
\hline Removal of calf $(R)$ & 1 & NS & NS & NS & NS & NS & NS & NS & NS & NS \\
\hline Calf $\operatorname{sex}(C)$ & 1 & NS & $* *$ & $* *$ & $* *$ & NS & $\dagger$ & NS & NS & NS \\
\hline Year $(\mathrm{Y})$ & 3 & $* * *$ & $* * *$ & $\dagger$ & $\dagger$ & $* *$ & **** & $* * *$ & $* * *$ & $* * *$ \\
\hline $\mathbf{S} \times \mathbf{R}$ & 1 & NS & NS & NS & NS & NS & NS & NS & NS & NS \\
\hline $\mathbf{s} \times \mathbf{C}$ & 1 & NS & NS & NS & NS & NS & NS & NS & NS & NS \\
\hline $\mathrm{R} \times \mathrm{C}$ & 1 & NS & NS & NS & NS & NS & NS & NS & NS & NS \\
\hline $\mathbf{S} \times \mathbf{Y}$ & 3 & NS & NS & NS & NS & NS & NS & NS & $*$ & NS \\
\hline $\mathbf{R} \times \mathbf{Y}$ & 3 & NS & NS & NS & NS & NS & NS & NS & NS & NS \\
\hline$C \times Y$ & 3 & NS & NS & NS & NS & NS & NS & NS & NS & NS \\
\hline $\mathbf{S} \times \mathbf{R} \times \mathbf{C}$ & 1 & NS & NS & NS & NS & NS & NS & NS & NS & NS \\
\hline $\mathbf{S} \times \mathbf{R} \times \mathbf{Y}$ & 3 & NS & NS & $\dagger$ & $\dagger$ & NS & NS & NS & NS & NS \\
\hline$S \times C \times Y$ & 3 & NS & NS & NS & NS & NS & NS & NS & NS & NS \\
\hline $\mathbf{R} \times \mathbf{C} \times \mathbf{Y}$ & 3 & NS & NS & NS & NS & NS & NS & NS & NS & NS \\
\hline $\mathbf{S} \times \mathbf{R} \times \mathbf{C} \times \mathbf{Y}$ & 3 & $\dagger$ & $\dagger$ & $\dagger$ & + & NS & NS & NS & $\dagger$ & NS \\
\hline
\end{tabular}

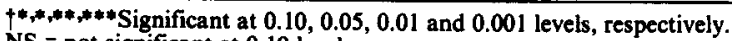

NS = not significant at 0.10 level.

iDegrees of freedom. Those for calving interval are given in parenthesis. 
Actual calf weaning weights observed during the study tended to follow a trend similar to that of growing season precipitation, i.e., 1984 and 1987 actual weaning weights were less $(P<0.001)$ than those for 1985 and 1986 (Table 5). Within either the 2 drier years, or the 2 years with more moisture, calf weaning weights were similar $(P>0.10)$.

Table 5. Least square means for calf production traits.

\begin{tabular}{|c|c|c|c|c|c|}
\hline Main effect & $\mathbf{N}$ & date & $\begin{array}{c}\text { Actual } \\
\text { weaning } \\
\text { weight }\end{array}$ & $\begin{array}{c}\text { Daily } \\
\text { gain, } \\
\text { birth to } \\
\text { weaning }\end{array}$ & $\begin{array}{c}205-\mathrm{d} \\
\text { adj } \\
\text { weaning } \\
\text { weight }\end{array}$ \\
\hline & & (Julian day) & $(\mathrm{kg})$ & $(\mathrm{kg} /$ day) & $(\mathrm{kg})$ \\
\hline Overall mean & 335 & 48 & 267 & 0.99 & 239 \\
\hline \multicolumn{6}{|l|}{ Supplement:1 } \\
\hline POST & 165 & 48 & 265 & 0.98 & 237 \\
\hline PRE & 170 & 47 & 271 & 1.00 & 242 \\
\hline \multicolumn{6}{|l|}{ Calf removal:1 } \\
\hline CONT & 168 & 48 & 266 & 0.98 & 238 \\
\hline $48-\mathrm{H}$ & 167 & 47 & 270 & 1.00 & 241 \\
\hline \multicolumn{6}{|l|}{ Calf sex: } \\
\hline Male & 156 & 48 & $277^{\mathrm{c}}$ & $1.03^{\mathrm{c}}$ & $248^{\mathrm{c}}$ \\
\hline Female & 179 & 47 & $258^{d}$ & $0.95^{\mathrm{d}}$ & $230^{d}$ \\
\hline \multicolumn{6}{|l|}{ Year: } \\
\hline 1984 & 99 & $52^{e}$ & $262^{f}$ & $1.00^{\mathrm{a}}$ & $242^{\mathrm{a}}$ \\
\hline 1985 & 89 & $46^{f}$ & $275^{\mathrm{e}}$ & $0.99^{a}$ & $240^{\mathrm{a}}$ \\
\hline 1986 & 76 & $46^{\mathrm{f}}$ & $276^{\mathrm{e}}$ & $0.99^{\mathrm{a}}$ & $239^{\mathrm{a}}$ \\
\hline 1987 & 71 & $46^{f}$ & $258^{f}$ & $0.97^{\mathrm{b}}$ & $235^{b}$ \\
\hline
\end{tabular}

ab,cd,et Column means within a main effect differ, $P<0.10,0.01$, and 0.001 , respectively. ISee Table 1 for description of treatments. No 2-way interactions $(P>0.10)$ involving supplement, calf removal, or sex of calf were detected.

With respect to weaning weights, however, differences in 205day adjusted weights among year were less meaningful than those for actual weaning weights $(P<0.10$ vs $P<0.001$, Tables 4 and 5); this indicates that some of the difference in actual weaning weights among years was caused by differences in calf age at weaning. In our study, weaning age varied from 225 days in 1984 to 242 days in 1986.

Main effect means for calf birth dates for 1984 are given in Table 5 as a starting point but, for that year, birth dates were not influenced by treatment. In subsequent years, calf birth dates reflected conception dates during the previous year. Least square mean birth dates by year for 1985 through 1987 were the same, i.e., Julian day 46 (or $15 \mathrm{Feb}$.), a date 6 days earlier $(P<0.001$ ) than the 1984 birth date. Calculated mean conception date for the final 3 call crops (1985 to 1987) was Julian day 129 (or 9 May); this would indicate that most cows bred during the first estrous cycle because the breeding season started in late April each year. Calving interval was less $(P<0.01)$ between 1984 and 1985 than for any of the subsequent years (Table 6).

Fall pregnancy rates remained high throughout the study (90 to 93\% among years) and were not influenced $(P>0.10)$ by treatment or year (Table 6). Year-to-year variation $(P<0.001)$ in cow BC scores at the start of breeding resulted largely from the high $B C$ in 1986 vs those for other years. Much of the comparatively high BC in 1986 may have been attributable to the observer who scored cows that year. As noted earlier, the same experienced observer assigned BC scores in all years except 1986 , when a less experienced individual assigned scores.

Cow BW changes varied $(P<0.001)$ among years, but these changes did not appear to be related to precipitation patterns. In each case, however, greater spring BW losses were followed by greater compensatory, summer-to-fall BW gains; this point is dealt with in greater detail in the subsequent section on protein supplementation effects.

\section{Protein Supplementation Effects}

At weaning, calves from PRE cows tended to be slightly heavier $(P=0.17)$ than calves from POST cows did, whether data were expressed as actual or as 205-day adjusted weaning weights (Table 5). Other studies have shown inconsistencies in the response of calf weaning weight to protein supplements fed to range cows during the previous winter-spring period. Bellido et al. (1981) and Clanton (1982) reported increased weaning weights from protein-supplemented vs unsupplemented cows. Flushing cows for a 4-wk postpartum period increased weaning weights of their calves compared with those from nonflushed cows (Wettemann et al. 1986). Sanson et al. (1990) found no difference in weaning weights of calves from cows grazing Nebraska Sandhill winter range forage and fed a high-protein supplement vs those fed the same supplement plus ear corn or those fed ear corn alone. Likewise. DelCurto et al. (1990) reported no difference in calf weaning weights in a study where cows grazed dormant tall-grass prairie forage and were fed sup-

Table 6. Least square means for cow body condition, body weight (BW) changes and reproductive performance traits.

\begin{tabular}{|c|c|c|c|c|c|c|c|}
\hline \multirow[b]{2}{*}{ Main effect } & \multirow[b]{2}{*}{$\mathbf{N}^{1}$} & \multirow[b]{2}{*}{$\begin{array}{l}\text { Cow body } \\
\text { condition }\end{array}$} & \multirow{2}{*}{$\begin{array}{l}\text { Fall } \\
\text { pregnancy } \\
\text { rate, } \%\end{array}$} & \multirow[b]{2}{*}{$\begin{array}{c}\text { Calving } \\
\text { interval, } \mathrm{d}\end{array}$} & \multicolumn{3}{|c|}{ Cow BW changes, $\mathrm{kg}$} \\
\hline & & & & & $\begin{array}{l}\text { Jan.- } \\
\text { Apr. }\end{array}$ & $\begin{array}{l}\text { Apr.- } \\
\text { Oct. }\end{array}$ & $\begin{array}{l}\text { Jan.- } \\
\text { Oct. }\end{array}$ \\
\hline Overall mean & $335(236)$ & 4.7 & 92 & 363 & -78 & 83 & 5 \\
\hline $\begin{array}{l}\text { Supplement: } \\
\text { POST } \\
\text { PRE }\end{array}$ & $\begin{array}{l}165(116) \\
170(120)\end{array}$ & $\begin{array}{l}4.5^{f} \\
4.9^{\mathrm{e}}\end{array}$ & $\begin{array}{l}92 \\
92\end{array}$ & $\begin{array}{l}364 \\
362\end{array}$ & $\begin{array}{l}-85^{\circ} \\
-70^{f}\end{array}$ & $\begin{array}{l}88^{c} \\
78^{d}\end{array}$ & $\begin{array}{l}3^{b} \\
8^{a}\end{array}$ \\
\hline $\begin{array}{l}\text { Calf removal: }{ }^{2} \\
\text { CONT } \\
48-\mathrm{H}\end{array}$ & $\begin{array}{l}168(120) \\
167(116)\end{array}$ & $\begin{array}{l}4.7 \\
4.7\end{array}$ & $\begin{array}{l}91 \\
93\end{array}$ & $\begin{array}{l}364 \\
362\end{array}$ & $\begin{array}{l}-76 \\
-79\end{array}$ & $\begin{array}{l}81 \\
85\end{array}$ & $\begin{array}{l}5 \\
6\end{array}$ \\
\hline $\begin{array}{l}\text { Calf sex: } \\
\text { Male } \\
\text { Female }\end{array}$ & $\begin{array}{l}156(112) \\
179(124)\end{array}$ & $\begin{array}{l}4.6^{\mathrm{b}} \\
4.8^{\mathrm{a}}\end{array}$ & $\begin{array}{l}93 \\
91\end{array}$ & $\begin{array}{l}364 \\
362\end{array}$ & $\begin{array}{l}-78 \\
-77\end{array}$ & $\begin{array}{l}82 \\
84\end{array}$ & $\begin{array}{l}4 \\
7\end{array}$ \\
\hline $\begin{array}{c}\text { Year: } \\
1984 \\
1985 \\
1986 \\
1987\end{array}$ & $\begin{array}{l}99- \\
89(89) \\
76(76) \\
71(71)\end{array}$ & $\begin{array}{l}3.8^{\mathrm{i}} \\
4.6^{\mathrm{h}} \\
6.0^{\mathrm{g}} \\
4.4^{\mathrm{h}}\end{array}$ & $\begin{array}{l}92 \\
91 \\
93 \\
90\end{array}$ & $\begin{array}{l}359^{f} \\
366^{\circ} \\
365^{\circ}\end{array}$ & $\begin{array}{l}-81^{\mathrm{g}} \\
-86^{\mathrm{z}} \\
-62^{\mathrm{h}} \\
-80^{\mathrm{g}} \\
\end{array}$ & $\begin{array}{l}84^{\text {gh }} \\
89^{\mathrm{g}} \\
76^{\mathrm{i}} \\
82^{\mathrm{h}} \\
\end{array}$ & $\begin{array}{r}3^{\mathrm{h}} \\
3^{\mathrm{h}} \\
14^{\mathrm{a}} \\
2^{\mathrm{h}} \\
\end{array}$ \\
\hline
\end{tabular}

ab,ed,ef,shi Column means within main effect differ, $P<0.10,0.05,0.01$, and 0.001 , respectively.

'Numbers in parentheses are for calving interval data.

2See Table 1 for description of treatments. No two-way interactions $(P>0.10)$ involving supplementation, calf removal, or sex of calf were detected. 
plements containing either 13,25 , or $39 \% \mathrm{CP}$.

The PRE supplemented cows had greater $(P<0.01) \mathrm{BC}$ at the start of breeding and lost less $(P<0.01) \mathrm{BW}$ during the spring supplementation period (January to April) than did POST cows (Table 6). When viewed according to the results of DelCurto et al. (1990), the longer period of high-protein $(41 \% \mathrm{CP})$ supplementation to the PRE cows (Table 2) would be expected to improve their $\mathrm{BC}$ and reduce their spring $\mathrm{BW}$ loss compared with POST cows. DelCurto et al. (1990) concluded that beef cow BC and BW losses during the winter were minimized when they were fed a $39 \% \mathrm{CP}$ supplement vs 13 or $25 \%$ CP supplements. Lusby and Wettemann (1988) reported that cows fed higher levels of a protein supplement gained more BW and lost less BC during precalving than cows fed low levels of supplemental protein. In contrast, however, Wettemann et al. (1986) reported that, while postpartum flushing of cows $\left(4.5 \mathrm{~kg} \cdot \mathrm{cow}^{-1} \cdot \mathrm{day}^{-1}\right.$ of a $20 \% \mathrm{CP}$ cottonseed meal/ground corn supplement for $4 \mathrm{wk}$ ) improved their BW change profile, it failed to alter $\mathrm{BC}$. The authors attributed the lack of $\mathrm{BC}$ response to greater demand on body reserves caused by increased milk production.

The POST-supplemented cows gained more $(P<0.05)$ BW during the summer-fall lactating period (April to October); however, for the total period (January through October), PRE cows had slightly greater $(P<0.10)$ BW gains than POST cows did (Table 6). Greater summer gains by POST cows presumbly reflected compensatory BW gains (because of their greater winter BW losses); similar compensatory gains have been reported by Clanton (1982) and DelCurto et al. (1990). A supplement $X$ year interaction $(P<0.05)$ for BW change from April to October was detected (Table 4) and was attributed to a lack of similar treatment response among year. From 1984 through 1986, during the April to October period, cows in the POST group gained 15,14 , and $11 \mathrm{~kg}$ more than those in the PRE group by respective year; in 1987, however, this advantage of POST over PRE cows declined to $1 \mathrm{~kg}$.

Weight changes from October of each study year to January of the subsequent year were analyzed but results are not presented. These changes were negligible in each case, and were not influenced $(P>0.10)$ by either treatments imposed or interactions among these treatments.

According to Selk et al. (1988), BC before calving and at the start of breeding, along with BW changes between 2 and 4 months before parturition, are major factors that influence pregnancy rates in range cows. In our study, PRE supplementation increased cow $\mathrm{BC}$ at breeding and minimized spring BW loss compared with POST supplementation as discussed earlier; however, reproductive performance as measured by fall pregnancy rate and calving interval (Table 6), as well as by calf birth date (Table 5), was not influenced $(P>0.10)$ by supplemental treatment. This finding closely parallels those of Sanson et al. (1990) and DelCurto et al. (1990). In these 2 latter studies, fall pregnancy rates averaged 90 and $91 \%$, respectively; in our study, pregnancy rates averaged $92 \%$. It would seem doubtful that cows on any of the treatments in the above studies (Sanson et al. 1990, DelCurto et al. 1990 or the present study) were deficient in total dietary protein. In other studies that included unsupplemented control cows (Bellido et al. 1981, Clanton 1982), or those fed very restricted levels of protein (Sasser et al. 1988), a beneficial reproductive response to protein supplementation has been reported. In a recent review, Randel (1990) cited 9 studies that compared fall pregnancy rates between cows fed adequate vs those fed inadequate precalving dietary protein levels; unweighted fall pregnancy averages over the 9 studies were 80 and $55 \%$, respectively.

In our study, the observation that POST cows performed as well as PRE cows, even though POST cows had greater spring BW losses and lower BC at breeding, was largely attributable to accelerated BW gains by POST cows during breeding. In earlier research, modest prepartum BW losses (Wiltbank et al. 1962) or early postpartum BW losses (Warren et al. 1988), did not influence subsequent reproductive performance, provided cows were on adequate (or high) nutritional levels during breeding.

\section{Calf Removal and Sex of Calf Effects}

During the calf removal periods in our study, physical separation of calves from their dams did not appear unduly stressful for either the cows or their calves. However, when calves were reunited with cows following the removal period, considerable short-term confusion was evident. At this point, calves were ready to nurse any willing cow and did so in many cases; it was not uncommon to observe some individual cows nursing as many as 4 calves for a limited time. Our cows and their calves were identified individually, thereby allowing calves to be paired with their rightful dam with minimal effort after the initial flurry of excitement subsided.

The 48-H removal treatment had no effect $(P>0.10)$ on any of the traits measured in our study (Tables 5 and 6). For some variables, there could be little or no reason to suspect that shortterm calf removal would have measurable influences (e.g., cow BC and BW changes); nevertheless, these data were included to illustrate that no real differences in these traits existed among calf removal treatment groups.

Previous research involving temporary calf removal has produced varying results. Wettemann et al. (1986) summarized results of a regional experiment (i.e., trials conducted in 6 different states) that indicated reproductive performance of cows was not improved by $48-\mathrm{H}$ calf removal before breeding either in flushed or nonflushed cows. Failure to improve reproductive performance by calf removal treatment also was reported by Makarechian and Arthur (1990), Lishman and Harwin (1985), and Warren et al. (1988). Conversely, others have demonstrated improved reproductive performance as a result of short-term calf removal treatment (Dunn et al. 1985, McCartney et al. 1990, and Smith et al. 1979).

Short et al. (1990) expressed caution regarding the use of temporary calf removal treatments; their primary concerns were increased potential for calfhood diseases and possible reductions in weaning weights. In a recent Canadian study, $5 \%$ weaning weight reductions were attributable to a 48-hour calf removal treatment (McCartney et al. 1990). In contrast to these findings, our study and several others (Warren et al. 1988, Makarechian and Arthur 1990) have shown that calf removal treatments had no adverse effects on health or weaning weight of calves.

Calf gains from birth to weaning, as well as actual and adjusted weaning weights of steer calves, exceeded $(P<0.01)$ those of heifer calves (Table 5). The female-to-male BW ratio for adjusted weaning weight was 1.08. Sex of calf also influenced cow BC scores at the start of breeding with cows nursing female calves having higher $(P<0.10) \mathrm{BC}$ than cows nursing male calves. Neither cow BW changes nor reproductive traits were influenced $(P<0.10)$ by sex of calf. Guthrie et al. (1991) reported that 2-and 3-yr-old range cows nursing female calves had higher $(P<0.05) \mathrm{BC}$ at breeding and shorter $(P<0.01)$ postpartum intervals than those with male calves. According to Short et al. (1990), calf effects on postpartum reproduction are related to growth rate differences of the calves and the amount of milk they consume; cows with fast-growing, larger calves and(or) those consuming more milk are more likely to have longer postpartum intervals.

\section{Conclusions and Management Implications}

Beginning the winter-spring supplemental feeding prepartum essentially doubled the length (and cost) of the supplemental feeding period compared with beginning supplementation postpartum. The longer feeding period resulted in no improvement in reproduction and only a very modest improvement in calf weaning weight. 
At present calf price: feed cost relationships (e.g., $\$ 2.20 / \mathbf{k g}$ for calves and $\$ .29 / \mathrm{kg}$ for the supplement), plus consideration of labor and transportation costs for supplementation, the longer feeding period would not be profitable. The $48-\mathrm{H}$ calf removal treatment (combined with either supplement treatment) failed to improve reproductive performance, but did not reduce calf weaning weights compared with the CONT treatment. Therefore, temporary calf removal, as conducted in this study, could not be recommended as a useful tool for improving reproductive performance.

In retrospect, we recognize that control cows in our experiment (i.e., POST supplemented and CONT calf removal cows) were sufficiently high in productivity that improvement beyond these levels would have been quite difficult, and perhaps not within practical expectations of the treatments imposed. Least square means of the control cow data show that they bred early during the breeding season, had high fall pregnancy rates (e.g., 91\%), calved early in the calving season, maintained calving intervals of $<365$ day, and produced calves that gained almost $1 \mathrm{~kg}$ /day during the suckling period.

Short et al. (1990) pointed out that, for most production systems, maximum fertility would not be the most profitable level, most likely because of the high cost of implementing the necessary management to promote such levels. Optimum fertility rate (as defined by Short et al. 1990) is that rate which returns the greatest profit over a period of time. We feel that our control cows may have reached (or have been very close to) an optimum fertility rate for the prevailing environment.

Although treatments used in our study did not improve reproduction, they have proven beneficial in other situations. Wallace (1988) reported an increased reproductive performance of 2-yr-old cows fed both a pre- and postpartum CP supplement compared with feeding the same supplement only during the postpartum period. Both Williams (1990) and Short et al. (1990) emphasized the value of $48-\mathrm{H}$ calf removal when used in association with an estrus synchronizing treatment. Hence, our results should not be applied universally to beef cow/calf production systems.

\section{Literature Cited}

Bellido, M.M., J.D. Wallace, E.E. Parker, and M.D. Finkner. 1981. Influence of breed, calving season, supplementation and year on productivity of range cows. J. Anim. Sci. 52:455-462.

Bellows, R.A., R.E. Short, and G.V. Richardson. 1982. Effects of sire, age of dam and gestation feed level on dystocia and postpartum reproduction. J. Anim. Sci. 55:18-27.

BIF. 1990. Guidelines for uniform beef improvement programs. USDA Ext. Bull. 1020 6th Ed. Beef Improvement Federation, Stillwater, Okla.

Clanton, D.C. 1982. Crude protein in range supplements, p. 228-237. In. F.N. Owens (ed.), Protein Requirements for Cattle. Symposium. Oklahoma State Univ. MP 109, Stillwater, Okla.

DelCurto, T., R.C. Cochran, L.R. Corah, A.A. Beharka, E.S. Vanzant, and D.E. Johnson. 1990. Supplementation of dormant tallgrass-prairie forage: II. Performance and forage utilization characteristics in grazing beef cattle receiving supplements of different protein concentrations. $J$. Anim. Sci. 68:532-542.

Dunn, T.G., M.F. Smith, G.A. Gaverick, and C.W. Foley. 1985. Effects of 72-h calf removal and/or gonadotropin releasing hormone in luteinizing hormone release and ovarian activity in postpartum beef cows. Theriogenology 23:767-776.

Guthrie, M.J., E.E. Parker, G.M. Southward, and J.D. Wallace. 1991. Supplemental energy vs protein for young cows grazing dormant blue grama rangeland. Proc. West. Sec. Amer. Soc. Anim. Sci. 42:19-22.
Judkins, M.B., J.D. Wallace, E.E. Parker, and J.D. Wright. 1985. Performance and phosphorus status of range cows with and without phosphorus supplementation. J. Range Manage. 38:139-143.

Lishman, A.W., and G.0. Harwin. 1985. Failure to induce ovulation by short-term removal in lactating beef cows in dry-lot. S. Afr. J. Anim. Sci. 15:21-22.

Lusby, K.S., and R.P. Wettemann. 1988. Wheat middlings vs soybean meal and corn/soybean supplements at two protein levels for wintering spring calving beef cows. Oklahoma Agr. Exp. Sta. MP-125:72-75.

Makarechian, M., P.F. Arthur. 1990. Effects of body condition and temporary calf removal on reproductive performance of range cows. Theriogenology 34:435-443.

McCartney, D.H., D.T. Spurr, W.F. Cates, A.D. Borth, and R.J. Mapletof. 1990. The effectiveness of 48-hour calf removal, Syncro-mate B or prostaglandin treatments in advancing the breeding season of beef cows. Theriogenology 34:1139-1148.

Odde, K.G., G.H. Kiracofe, and R.R. Schalles. 1986. Effect of forty-eighthour calf removal, once-or-twice daily suckling and norgestomet on beef cow and calf performance. Theriogenology 26:371-381.

Randel, R.D. 1990. Nutrition and postpartum rebreeding in cattle. J. Anim. Sci. 68:853-862.

Richards, M.W., J.C. Spitzer, and M.B. Warner. 1986. Effect of varying levels of postpartum nutrition and body condition at calving on subsequent reproductive performance in beef cattle. J. Anim. Sci. 62:300-306.

Sanson, D.W., D.C. Clanton, and I.G. Rush. 1990. Intake and digestion of low-quality meadow hay by steers and performance of cows on native range when fed protein supplements containing various levels of corn. J. Anim. Sci. 68:595-603.

SAS. 1985. SAS User's Guide: Statistics, Version 5 ed. SAS Institute, Inc., Cary, N.C.

Sasser, R.G., R.J. Williams, R.C. Bull, C.A. Ruder, and D.G. Falk. 1988. Postpartum reproductive performance in crude protein-restricted beef cows: return to estrus and conception. J. Anim. Sci. 66:3033-3039.

Selk, G.E., R.P. Wettemann, K.S. Lusby, J.W. Oltjen, S.L. Mobley, R.J. Rasby, and J.C. Garmendia. 1988. Relationship among weight change, body condition and reproductive performance of range beef cows. $J$. Anim. Sci. 66:3153-3159.

Short, R.E., and D.C. Adams. 1988. Nutritional and hormonal interrelationships in beef cattle reproduction. Can. J. Anim. Sci. 68:29-39.

Short, R.E., R.A. Bellows, R.B. Staigmiller, J.G. Berardinelli, and E.E. Custer. 1990. Physiological mechanisms controlling anestrus and infertility in postpartum beef cattle. J. Anim. Sci. 68:799-816.

Smith, M.F., W.C. Burrell, L.D. Shipp, L.R. Sprott, W.N. Songster, and J.N. Wiltbank. 1979. Hormone treatments and use of calf removal in postpartum beef cows. J. Anim. Sci. 48:1285-1294.

Wallace, J.D. 1988. Supplemental feeding options to improve livestock efficiency on rangelands. p. 92-100. In: R.S. White and R.E. Short (eds.), Achieving efficient use of rangeland resources. Sept. 1987. Fort Keogh Res. Symp., Montana Agr. Exp. Sta.

Warren, W.C., J.C. Spitzer, and G.L. Burns. 1988. Beef cow reproduction as affected by postpartum nutrition and temporary calf removal. Theriogenology 29:997-1006.

Wettemann, R.P., G.M. Hill, M.E. Boyd; J.C. Spitzer, D.W. Forrest, and W.E. Beal. 1986. Reproductive performance of postpartum beef cows after short-term calf separation and dietary energy and protein supplementation. Theriogenology 26:433-443.

Williams, G.E. 1990. Suckling as a regulator of postpartum rebreeding in cattle: A review. J. Anim. Sci. 68:831-852.

Wiltbank, J.N., W.W. Rowden, J.E. Ingalls, K.E. Gregory, and R.M. Koch. 1962. Effects of energy level on reproductive phenomena of mature Hereford cows. J. Anim. Sci. 21:219-225. 